\title{
Legal Control of Covid-19 Pandemic by the Government of the Special Capital Region of Jakarta
}

\author{
Gunardi Gunardi ${ }^{1 *}$ Rasji Rasji $^{1}$ \\ ${ }^{1}$ Lecturer of the Faculty of Law, Universitas Tarumanagara, Jakarta 11440, Indonesia \\ "Corresponding author. Email: gunardi@fh.untar.ac.id
}

\begin{abstract}
The Covid-19 pandemic has hit Indonesia since March 2020. One of the areas most affected by Covid-19 is the Special Capital Region of Jakarta. Covid-19 has spread rapidly and has an impact on public health problems, even causing death. The Government of the Special Capital Region of Jakarta is experiencing difficulties in preventing the spread of Covid-19 and coping with its effects, due to high community interaction. One of the steps taken by the Government of the Special Capital Region of Jakarta is legal control of the Covid-19 pandemic, by establishing statutory regulations, policy regulations, and law enforcement. The types of regulations and policies that it forms are regional regulations, governor regulations, governor decrees, circulars, instructions, appeals, and various announcements. These regulations and policies are the legal basis and basis for the government's authority to form a covid-19 task force, establish hospitals for handling Covid-19, enforce health protocols, temporarily close public places, limit office and industrial activities, limit social interactions, limit public transportation., oblige to work from home, oblige to study from home, oblige to worship from home, and provide economic assistance to the community. The Government of the Special Capital Region of Jakarta also carries out law enforcement through monitoring the implementation of regulations and policies, preventing the flow of people into or out of the Special Capital Region of Jakarta, checking the use of health protocol facilities, closing entertainment venues and public places, not granting crowd permits, and imposition of sanctions. fines to members of the public who violate health protocols. The efforts of the Government of the Special Capital Region of Jakarta have succeeded in reducing the rate of spread of Covid-19, maintaining public health, treating community members affected by Covid-19, and reducing the number of world casualties.
\end{abstract}

\section{Keywords: The Covid-19 Pandemic, Legal Control, Special Capital Region Government Jakarta}

\section{INTRODUCTION}

The Indonesian nation is currently pursuing the development of various state sectors, in order to achieve the status of an advanced Indonesia. Various state sectors have been, are being, and continue to be empowered to support the achievement of this status. Various strategies and policies continue to be directed and take sides with the efforts to advance the country. As a rule of law [1], these various strategies and policies are incorporated into regulations, therefore Indonesia continues to form regulations that serve as guidelines and legal basis for various activities of the Indonesian nation.

Recently, the above efforts have been hampered by a virus called Corona Virus Disease 2019, which is abbreviated as Covid-19 [2]. This virus initially appeared in China's Wuhan Province in January 2020 [3]. The spread of this virus is very fast and the danger is very bad, so that in a short time Covid-19 spread throughout the world, so the World Health Organization (WHO) declared the Covid-19t virus has become a world pandemic [4]. As a result, all citizens of the world are very afraid of this virus, because it has caused millions of people to suffer from illness, even thousands of people have died. This virus not only attacks ordinary citizens, but also attacks health workers, doctors, and other medical personnel who treat it. Many hospitals that become places of treatment are unable to accommodate the number of patients exposed to this virus. As a result, many Covid-19 patients cannot be handled by health workers, which has an impact on the number of victims who have died. Data on world citizens exposed to positive Covid-19 as of April 20, 2020 were 2,418,845 people, 165,759 died, and 633,363 people were successfully cured [5].

Since the beginning of March 2020, the Covid-19 virus has penetrated into Indonesian territory. Many Indonesians became sick and even died as a result of this virus attack. As a result of the rapid spread of this virus, in a short time until April 20, 2020, the Republican Ministry of Health recorded the number of positive cases of Covid-19 was 6,760 patients, the number of patients treated was 5,423 
people, the number of patients recovered 747 people, the number of patients died 590 people, the number of PDP 16,343 people, and the number of ODP 181,770 people [6]. One of the areas in Indonesia most affected by Covid-19 is the Special Capital Region of Jakarta (DKI Jakarta). Covid19 has spread rapidly and has an impact on the health problems of the people of DKI Jakarta, even causing the death of DKI Jakarta residents. At the start of the pandemic until April 20, 2020, DKI Jakarta Province occupied the first rank of provinces affected by Covid-19 in Indonesia with 3,097 positive cases of Covid-19, 230 patients recovered, and 287 patients died [7].

The DKI Jakarta government has moved quickly to take measures to prevent the spread of the virus, take care of people who are detected positive for the virus by providing health services, hospitals to treat patients affected by Covid19, function doctors and other health workers to treat patients affected by Covid-19. However, these efforts have not been able to prevent the spread and eliminate the virus from DKI Jakarta, even the number of sick sufferers and deaths due to this virus attack continues to increase. The high intensity of community interaction adds to the difficulty of the DKI Jakarta Government to prevent the spread of Covid-19 and overcome its effects. Office activities, trade and industry, movement of people from and out of Jakarta, and other social activities were prevented, thus supporting the wider spread of Covid-19.

One of the steps taken by the DKI Jakarta Government is a legal approach. The DKI Jakarta government views the law as indispensable to become the basis for government legality in preventing and controlling community movements. Laws regulating the restriction and control of community movement will prevent the spread of Covod-19 and reduce its impact on public health problems. The law that has been enacted by the central government is deemed insufficient as a basis for legality of operational and technical actions by the DKI Jakarta Government. Many aspects related to the regional autonomy authority of DKI Jakarta need to be regulated legally, so that government autonomy actions can be carried out legally. How is the legal control of Covid-19 by the DKI Jakarta Provincial Government in preventing the spread and overcoming the impact of Covid-19? This problem is interesting to research, in order to find out the efforts of the DKI Jakarta Government in preventing and controlling the spread and impact of Covid-19 in the DKI Jakarta area.

\section{METHOD}

A legal problem can be resolved using data that answers the problem. Scientifically, this data is obtained through research using certain research methods. In legal research, there are two research methods that can be used in accordance with the scope of the study. If you want to study legal problems empirically, the data needed to answer these legal problems is data obtained through empirical legal research methods. However, if you want to study legal issues normatively, the data needed to answer these legal problems is data obtained through normative legal research methods [8].

During the Covid-19 pandemic, empirical legal research methods were very difficult to implement to prevent the spread and control the impact of Covid-19, considering the spread of Covid-19 was very fast and very dangerous Covid-19 to human health problems. In addition, the implementation of strict health protocols makes empirical data difficult to obtain. Therefore, legal research that can be carried out to answer the above problems is normative legal research. Normative legal research is legal research on normative data contained in various written legal materials [9]. Written legal materials are materials where written legal data is found. Therefore, this research is a research conducted on written legal materials, in the form of statutory regulations, policy regulations, and doctrines found in books, journals, papers and articles on the internet. These various legal materials are studied and assessed for their relevance with the data needed to answer the problem. The type of data required is secondary data, namely the type of data that has been processed and presented by researchers or authors of regulations, books, journals, and articles on the internet. Furthermore, data relevant to the research problem are collected, identified, processed, then analyzed using a qualitative approach. A qualitative approach is a data approach that has appropriate qualifications (relevant quality) with the problem being studied [10]. In the end, the results of this analysis are concluded to be the answer to the problems examined in this study.

\section{DISCUSSION}

\subsection{The Nature of the Law}

Indonesia is a welfare law state. The consequence is that the Government of Indonesia is obliged to create the welfare of its people [11]. The government is obliged to be involved in various aspects of people's lives, so that the people are prosperous. The suffering of the people due to the Covid-19 attack, which resulted in the people being not prosperous, is the responsibility of the government. Therefore, the DKI Jakarta Government must be responsible for overcoming the attacks and impacts of Covid-19 on its citizens, and trying to restore the health and happiness of its citizens.

As a rule of law, the responsibility of the government must be based on the law, considering that one of the characteristics of a rule of law is the power of government based on the law [12]. The existence of the law is very important for the government to control the spread and impact of Covid-19. The legal essence referred to is the regulation made by the government, including the DKI Jakarta Government. Regulations here are regulatory norms that have general and abstract characteristics, meaning norms that regulate the behavior of the general public and apply continuously [13]. The DKI Jakarta Government needs laws that regulate the behavior of the people of DKI Jakarta, so that people's behavior changes according to the 
need to prevent the spread of Covid-19 and overcome its impact on society.

According to Law Number 12 of 2011 concerning the Formation of statutory regulations, the essence of law above includes the 1945 Constitution of the Republic of Indonesia (UUD 1945), Laws or Government Regulations in Lieu of Law (UU / PERPU). , Government Regulations (PP), Presidential Regulations (Perpres), Provincial Regulations (Perda Provinsi), and District / City Regulations (Perda Kabuaten / City), as well as regulations stipulated by the People's Consultative Assembly, the People's Representative Council, the Regional Representative Council, The Supreme Court, the Constitutional Court, the Supreme Audit Agency, the Judicial Commission, Bank Indonesia, Ministers, agencies, institutions, or commissions at the same level as established by Law or the Government at the behest of the Law, Provincial Regional People's Representative Council, Governor, Council District / City Regional People's Representatives, Regents / Mayors, Village Heads or equivalent.

At this time, the existing laws and regulations are not sufficient to control the Covid-19 pandemic. The rapid spread and level of danger of Covid-19 for human health is a new phenomenon for the people of Indonesia, even the world community. The existing legal norms in Indonesia have not been able to overcome the Covid-19 phenomenon. For this reason, there needs to be legal norms that are able to regulate changes in people's behavior, apply, and can be forced on the community, so that the phenomenon of the spread of Covid-19 can be prevented and its effects can be overcome by the government. This is also needed by the DKI Jakarta Government to regulate the behavior of the people of DKI Jakarta in order to prevent the spread and overcome the impact of Covid-19 in DKI Jakarta.

\subsection{Legal Control by the Government of DKI Jakarta}

The DKI Jakarta Government is a regional government led by the Governor. The Governor of DKI Jakarta has two functions, namely as the head of the autonomous region and the representative of the central government in DKI Jakarta. The Governor of DKI Jakarta has the right, authority and obligation to regulate his regional autonomy affairs, and is also obliged to carry out central government programs in his region. Therefore, the Governor of DKI Jakarta and his staff are required to control the spread of Covid-19 and its effects in accordance with central government programs in the region and in accordance with the authority of regional autonomy.

The DKI Jakarta government has complex community characteristics. Various activities of the central government and autonomous regions, ethnic groups, indigenous peoples, culture, socio-political characteristics, trade in goods and services, and other diversity characterize the complex behavior of the people in DKI Jakarta. The legal approach is a very important consideration for the DKI Jakarta Government, so that the behavior of all components of society in the DKI Jakarta area can be controlled according to the need to prevent the spread and control of the impact of Covid-19. From the research results, the DKI Jakarta Government carries out legal control through two types of regulations, namely statutory regulations (wetgeving) [14) and policy regulations (beleidregel [15], pseudowetgeving [16], speigelrecht [17]) both made by the government. central government as well as by the DKI Jakarta Government.

Operationally, the control of Covid-19 through two types of regulations by the DKI Jakarta Government is carried out in four ways, namely:

a. Implementing laws and regulations and policy regulations made by the central government

The central government has regulated efforts to prevent the spread and control of the impact of Covid-19 with laws and regulations and policy regulations. The laws and regulations in question include laws, government regulations, government regulations, presidential decrees, and regulations, while policy regulations include circular letters (SE), instructions, warrants, and announcements. Substances related to health, occupational safety, occupational health, prevention of infectious disease outbreaks, finance for handling Covid-19, large-scale social restrictions (PSBB), determination of non-natural disasters for the spread of Covid-19, guidance for prevention and control of Covid-19, control of transportation, preventing people from entering and leaving Indonesia, implementing health protocols, and others. The DKI Jakarta government implements the laws and regulations of the central government policy towards the community to prevent the spread and overcome Covid-19 in the DKI Jakarta area.

b. Making and implementing the laws and regulations of DKI Jakarta

The DKI Jakarta Government makes statutory regulations in the form of 11 Regional Regulations and 11 governor regulations. These laws and regulations are intended to prevent the spread of and overcome Covid19 through an emergency hospital, Cobid-19 service facilities, restrictions on transportation facilities, implementation of PSBB, rationalization of civil servant income, reduced retribution, controlling incentives for health workers, eliminating administrative sanctions, giving awards to health workers who died, implementing discipline and enforcing health protocols, and implementing health protocol sanctions and PSBB.

c. Creating and implementing DKI Jakarta policy regulations

The DKI Jakarta government made and implemented 41 policy regulations in the form of 17 Governor Decrees, 11 Governor Decrees and related Services, 5 Governor Instructions, and 8 Governor Appeals. Through this policy regulation, the DKI Jakarta government prevents the spread of and overcomes Covid-19 by regulating the Covid-19 Cluster, implementing health protocols, implementing PSBB restrictions, temporarily suspending office activities, temporarily eliminating worship in places of worship, temporarily closing public places (places entertainment, tourist attractions, shops, 
malls), maintaining distance between residents, establishing an emergency response to the Covid-19 outbreak, Covid-19 funding, school learning from home, temporary closure of public libraries, prohibiting Eid homecoming, preventing the flow of residents out and into DKI Jakarta, examination of PCR tests, rapid antigen tests, designation of referral hospitals and patient care facilities, distribution of masks to residents, provision of independent isolation facilities, allocation of costs for Covid-19 prevention and control facilities, assistance for basic needs of DKI Jakarta residents, and other efforts to prevent and control Covid-19.

d. Law enforcement

The Government of the Special Capital Region of Jakarta also carries out law enforcement through supervision of the implementation of laws and regulations and policy regulations, preventing the entry or exit of the Special Capital Region of Jakarta, examining the use of health protocol facilities, closing entertainment venues. and public places, not giving permission to crowd, taking unannounced inspections, and imposing fines for members of the public who violate health protocols and PSBB. For example, law enforcement carried out from April 28, 2020 to May 10, 2020, the DKI Jakarta Government recorded 30,347 violations of the health protocol covering 379 online ojeg violations, 15,767 people not wearing masks, 3,964 workers not wearing gloves, 48 body temperature violations, 3,049 people. by motorbike / car without one KTP address, 5,958 the number of passengers exceeded 50 percent, 967 shops / traders violated operating hours, and 967 violated passenger distances [18].

The DKI Jakarta government has finally implemented social sanctions and fines for PSBB violators as regulated by DKI Jakarta Governor Regulation No.41 of 2020 concerning Imposition of Sanctions for Violations of PSBB Implementation in Handling Covid-19 in the Special Capital Region of Jakarta Province. The sanctions that are applied are the sanctions outlined in Article 11, namely:

(1) Any person who violates the prohibition to carry out activities with a number of more than 5 people in public places or facilities during the implementation of the PSBB is subject to sanctions: a. administrative written warning; b. social activities in the form of cleaning public facilities by wearing a vest; or c. administrative fines of at least Rp 100,000.00 and a maximum of $\operatorname{Rp} 250,000.00$.

(2) The imposition of sanctions as referred to in paragraph (1) shall be carried out by the Civil Service Police Unit and may be accompanied by the police.

The practice is that people who violate are subject to sanctions in the form of reprimands, push-ups, social sanctions in the form of cleaning public facilities by wearing an orange vest that reads "PSBB Violators", and fines. The efforts of the Government of the Special Capital Region of Jakarta have succeeded in reducing the spread of Covid-19, maintaining public health, caring for community members affected by Covid-19, and reducing the death toll, so that on 3 August 2020 the DKI Jakarta Government succeeded in lowering the ranking of the number of Covid cases. in Indonesia became the second rank after East Java Province.

\section{CONCLUSION}

Legal control for the Covid-19 pandemic by the DKI Jakarta Provincial Government is carried out in four ways. First, the government implements laws and regulations and policy regulations stipulated by the central government. The second is that the government makes new laws and regulations in the form of Blood Regulations and Governor regulations in accordance with the autonomous authority of the DKI Jakarta Government. Third, the government makes and implements policy regulations in the form of decrees, SEs, instructions, guidelines, and announcements in accordance with the administrative authority of the DKI Jakarta government. The fourth is the DKI Jakarta Government to enforce the law against violations of statutory regulations and policy regulations.

Through the four methods mentioned above, the DKI Jakarrta Government has succeeded in controlling and restricting community behavior in the fields of business, social, education, religion, health, business / business, government, and thus community participation. The restrictions are in the form of Health protocol, PSBB, prohibition of traveling outside or entering the area, closing locations for public activities, sudden inspection by law enforcement officials, calling for a healthy life, and imposing fines and administrative sanctions on people who violate the law, and other appeals. carried out by the DKI Jakarta Government. These efforts have reduced the rate of spread of Covid-19, positive cases of Covid-19, the number of victims who have died, and increased the number of people recovering from Covid-19 illness.

\section{REFERENCES}

[1] Indonesia. The 1945 Constitution of the Unitary State of the Republic of Indonesia. Article 1 paragraph (3).

[2] Minister of Health. Decree of the Minister of Health of the Republic of Indonesia Number HK. 01.07 / MENKES / 328/2020 concerning Guidelines for the Prevention and Control of Corona Virus Disease 2019 (Covid-19) in Office and Industrial Workplaces in Support of Business Continuity in Pandemic Situations. First Dictum.

[3] Gunardi, Rasji, Thalesia, Endah Arini. "Research Report on Legal Control Against the Impact of the Covid-19 Pandemic by the Central Government, the Special Capital Region Government of Jakarta, and the Banten Province". Jakarta: LPPM Untar, 2020. 1. 
[4] Ahmad Naufal Dzulfaroh. "Today in History: WHO Defines Covid-19 as a Global Pandemic". https://www.kompas.com/tren/read/2021/03/11/104000 165/hari-ini-dalam-sejarah-who-set-covid-19-aspandemic-global? 1.

[5] Gunardi, Rasji, Thalesia, Endah Arini. "Research Report on Legal Control Against the Impact of the Covid-19 Pandemic by the Central Government, the Special Capital Region Government of Jakarta, and the Banten Province". Jakarta; LPPM Untar, 2020. 1-2.

[6] Adi M Idhom, "Update Corona 20 April 2020 Indonesia and the World: Latest Data Info". https://tirto.id/update-corona-20-april-2020-indonesiadan-dunia-info-data-terkini-ePJ1. 20 April 2020.1.

[7] Adi M Idhom. "Update Corona 20 April 2020 Indonesia and the World: Latest Data Info", available at https://tirto.id/update-corona-20-april-2020-indonesiadan-dunia-info-data-terkini-ePJ1. 20 April 2020.2.

[8] Soerjono Soekanto. Introduction to Legal Research. Cet. I. Jakarta: UI-Press, 1981. 9-11.

[9] Soerjono Soekanto and Sri Mamudji. Normative Legal Research: A Brief Overview. Cet. II. Jakarta: CV. Rajawali, 1986.27.

[10] Soerjono Soekanto and Sri Mamudji. Normative Legal Research: A Brief Overview. Cet. II. (Jakarta: CV. Rajawali, 1986). 30.

[11] Rasji. "Testing of Policy Regulations in Indonesia (A Study of Circular Issued by the Government)". Dissertation. Jakarta: FH Untar, 2019. 84-87.

[12] Rasji. "Testing of Policy Regulations in Indonesia (A Study of Circular Issued by the Government)". Dissertation. Jakarta: FH Untar, 2019. 88-89.

[13] Maria Farida Indrati Soeprapto. Legislation, Processes and Techniques for Its Formation. Yogyakarta: Kanisius, 2007. 88.

[14] Maria Farida Indrati Soeprapto. Legislation, Processes and Techniques for Its Formation. Yogyakarta: Kanisius, 2007. 298-299.

[15] Abdul Rozak. "The Nature of Policy Rules", in www.negara Hukum.com, April 2 2015. 1.

[16] Bagir Manan and Kuantana Magmar. Several Indonesian Constitutional Law Issues. Bandung: Alumni, 1997.167.
[17] Safri Nugraha et al. State Administrative Law. Jakarta: FH UI, 2008.93.

[18] Jakarta Covid-19 Cluster. Data on Health Protocol Violators with Warning Sanctions in the DKI Jakarta Region, 2020. 1. 